\section{THE PRESERVATION OF NIAGARA ${ }^{1}$}

$N$ EARLY seven years ago Lord Dufferin, then governorgeneral of Canada, suggested to Gov. Robinson of New York that the governments of the province of Ontario and the state of New York should purchase such lands about Niagara Falls as would be required to give free access to the principal points of view, and serve to restore and preserve the natural scenery of the great cataract, beside securing to visitors freedom from those vexatious annoyances which now abound. Subsequently the governor-general called the attention of the government of Ontario to the matter, and recommended cooperation with the state of New York in accomplishing this purpose.

Later, in January, 1879, Gov. Robinson, in his annual message to the legislature of New York, presented this matter, and recommended the appointment of a commission to investigate the question, to confer with the Canadian authorities, to consider what measures were necessary, and to report the results to a succeeding legislature.

By resolution the commissioners of the State Survey were charged with the investigation. This commission included some of the most distinguished men of the state,Ex-Gov. Horatio Seymour, Vice-President of the United States, W. A. Wheeler, Lieut. -Gov. Dorsheimer, President Barnard of Columbia College, and others.

With breadth of view worthy of such men, they state in their report that, "under this resolution, it became the duty of the commissioners to ascertain how far the private holding of land about Niagara Falls has worked to public

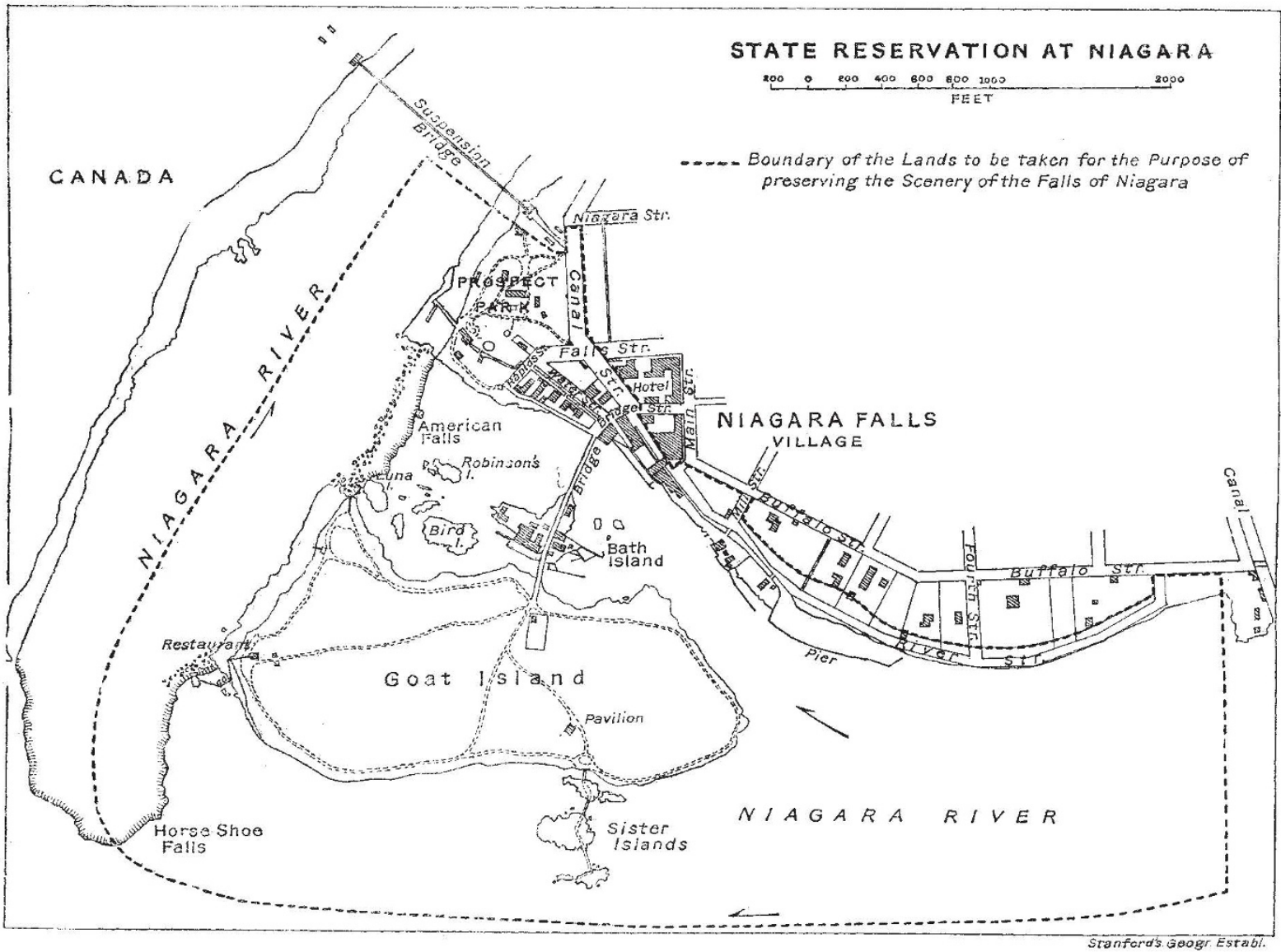

disadvantage through defacements of the scenery; to estimate the tendency to greater injury; and, lastly, to consider whether the proposed action by the state is necessary to arrest the process of destruction, and restore to the scenery its natural character." In pursuance of these objects, the commissioners instructed Mr. James T, Gardiner, director of the State Survey, to make an examination of the premises, and prepare for their consideration a project. He was assisted in this work by $\mathrm{Mr}$. Frederick Law Olmsted, the distinguished landscape-architect.

The examination showed that the destruction of the natural scenery which forms the framework of the Falls was rapidly progressing: unsightly structures and mills were taking the place of the beautiful woods that once overhung the rapids; the fine piece of primeval forest remaining on Goat Island was in jeopardy from projects I From Science. looking to making a showrround of the island; and every point from which the Falls could be seen on the American side was fenced in, and a fee charged for admission. It was found that, owing to the topography of the main shore, it was practicable to restore its natural aspect by clearing away the buildings from a narrow strip of land 100 to 800 feet broad and a mile long, and planting it with trees which would screen out from view the buildings of the village. When these trees should be grown, and the mills removed from Bath Island, and trees planted there, the falls and rapids would be again seen in the setting of natural foliage which formed so important an element in their original beauty. Every point from which the Falls could be seen would also become free of access by the plan proposed. A map was made showing just what lands should be taken to carry out these purposes. The commissioners adopted the plan of Mr. Gardiner 
and Mr. Olmsted, and recommended to the legislature of 1880 the passage of an Act to provide for acquiring title to the necessary lands by the exercise of the right of eminent domain, leaving it to a future legislature to consummate the purchase by appropriating the amount for the payment of the awards, if the sum should seem a reasonable price for the property. Such an Act passed the Assembly, but was defeated in the Senate, although the movement was supported by petitions signed by the most distinguished men of this and other countries. The report of the State Survey, with its complete descriptions, illustrations, and maps, then became the basis of a systematic effort on the part of a few determined friends of the Falls to educate and arouse public opinion to save the scenery of Niagara. Early in 1883 this movement ripened into the organisation of an association to promote legislation for preserving the scenery of the Falls of Niagara, $\mathrm{Mr}$. Howard Potter of New York being president, and Hon. J. Hampden Robb, chairman of the executive committee.

Through the efforts of this Niagara Falls association an Act was passed, in I883, providing for a commission, entitled "The commissioners of the state reservation at Niagara," and giving them power to proceed through the courts to condemn the lands needed. Ex-Lieut.-Gov. William Dorsheimer is the president of this board; and the other members are President Anderson of Rochester University, Hon. J. Hampden Robb, Hon. Sherman S. Rogers, and Andrew H. Green. With some modifications made necessary by changed conditions, they adopted the plan proposed by the State Survey. The lands selected were then surveyed, and their value appraised by a commission of very high character, appointed by the court, the total value of the lands being $\$ 1,433,429.50$. The report of the commissioners of the reservation was made to the present legislature, and a Bill to appropriate this sum was introduced. The Niagara Falls association worked in every part of the state to arouse public opinion to the importance of making this appropriation, and the commissioners laboured most earnestly among the legislators and the people. The battle was a hard one against ignorance and narrowminded selfishness; but the victory is complete. The legislature, by more than a two-thirds majority, has appropriated the $\$ 1,433,429.50$, and the governor has approved the Act.

After six years of almost continuous effort on the part of the active friends of this enlightened project, it is secured by a law which declares that the lands are purchased by the state in order that they may be "restored to, and preserved in, a state of nature," and that every part of them shall be for ever free of access to all mankind.

\section{NOTES}

WE understand that on the receipt by the Science and Art Department from the Foreign Office of a despatch from Her Majesty's Minister at Washington forwarding communications concerning the proposed change in the time for beginning the astronomical day, as recommended by the recent International Meridian Conference at Washington, the Lords of the Committee of Council on Education requested the following Committee to advise them as to what steps should be taken in the matter. Prof. J. C. Adams, F.R.S., the Astronomer-Royal, Capt. Sir F. Evans, K.C.B., R.N., the Hydrographer of the Navy, Gen. Strachey, R.E., C.S.I., F.R.S., Dr. Hind, F.R.S., and Col. Donnelly, R.E. In accordance with their recommendations copies of the Report of the Delegates to the International Prime Meridian Conference, at Washington, together with the resolutions adopted by that body, have been sent to various departments of the State, and to the following Societies, \&c. : Society of Telegraphic Engineers, Royal Astronomical Society, Royal Society, Submarine Telegraph Company, Eastern Telegraph
Company (Limited), Eastern and South African Telegraph Company (Limited), Eastern Extension, Australasia and China Telegraph Company (Limited), Railway Clearing House. They have been informed that these resolutions of the Prime Meridian Conference appear to my Lords of the Committee of Council to be such as commend themselves for adoption. But before informing the American Government to that effect their Lordships would be glad to receive the opinion of the various societies on the subject.

THE annual meeting for the election of Fellows of the Royal Society was held at Burlington House on Thursday, June 4, the President in the chair. The following were elected:-Major A. W. Baird, R.E., Philip Herbert Carpenter, D.Sc., Sir Andrew Clark, Bart., M.D., Andrew Ainslie Common, F.R.A.S., Staff-Commander Ettrick William Creak, R.N., Prof. Edward Divers, Henry Hicks, M.D., William Mitchison Hicks, M.A., Francis R. Japp, Ph. D., Arthur Milnes Marshall, M.D., Prof. Henry Newell Martin, D. Sc., Cornelius O'Sullivan, Prof. John Perry, Prof. Sydney Ringer, Sidney Howard Vines, D.Sc.

THE Davis lectures upon zoological subjects will be given in the Lecture Room in the Zoological Society's Gardens, Regent's Park, on Thursdays, at 5 p.m. The first was given on Thursday, June 4, the subject being "Rhinoceroses and their Extinct Allies," by Prof. Flower, LL.D., V.P.R.S. The others are :Thursday, June II, "Apes and Lemurs," by Dr. St. George Mivart, F.R.S. ; Thursday, June I8, "The Structure of the Swan," by Prof. W. K. Parker, F.R.S. ; Thursday, June 25, "The Domestic Cat," by J. E. Harting, F.L.S. ; Thursday, July 2, "Recent Advances in Zoology," by Prof. F. Jeffrey Bell, M.A. ; Thursday, July 9, "The Ancestors of Birds," by F. E. Beddard, M. $\Lambda$.; Thursday, July 16, "The Animals of New Guinea," by P. L. Sclater, F.R.S.

In the second edition of his work, "Sur l'Origine du Monde," M. Faye has promulgated the following hypothesis regarding the relations between the geological epochs and the stages of the terrestrial cosmogony. The history of the earth he divides into six stadia. The first is that in which the earth was a glowing ball. The second he calls the Anteroic period, in which total darkness supervened on the extinction of the earth's glow. The third is the Primary period, during which there was a feeble illumination from the sun, which was then just cuming into existence. During the Secondary period the sunlight went on increasing as the sun itself grew larger and assumed its proper shape. In the fifth stadium, which is that of the Tertiary period, there was complete solar illumination, and the sun soon attained the maximum of its activity; while in the last stadium, that of the Quaternary period, there has been a slight diminution of the solar activity (rather surmised than demonstrated), accompanied by the diappearance of every cosmogonic influence and the establishment of perfect stability in almost all directions. Oscillations in the earth's crust and feeble volcanic manifestations are almost the only instances of cosmogonic change still observable.

WE have received from MM. Fol et Sarasin a copy of a paper by them on the depth to which the light of the sun will penetrate into the sea. It will be remembered that in November last they recounted the results of their experiments on the same subject in the Lake of Geneva. The present paper describes similar experiments made in the Mediterranean off the zoological station and harbour of Villefranche. By means of photographic plates they have proved that in the month of March, in the middle of a sunny day, the rays of the sun do not penetrate beyond 400 metres below the surface of the Mediterranean. This is established by seven separate experiments, at varying 